\title{
Modulation of the oscillatory mechanics of lung tissue and the oxidative stress response induced by arginase inhibition in a chronic allergic inflammation model
}

Luciana RCRB Aristoteles ${ }^{1,4^{*}}$, Renato F Righetti ${ }^{1}$, Nathalia Montouro Pinheiro ${ }^{1}$, Rosana B Franco ${ }^{1}$, Claudia M Starling ${ }^{1}$, Julie CP da Silva ${ }^{1}$, Patrícia Angeli Pigati ${ }^{1}$, Luciana C Caperuto ${ }^{3}$, Carla M Prado ${ }^{3}$, Marisa Dolhnikoff', Milton A Martins ${ }^{1}$, Edna A Leick ${ }^{1}$ and Iolanda FLC Tibério ${ }^{1,4^{*}}$

\begin{abstract}
Background: The importance of the lung parenchyma in the pathophysiology of asthma has previously been demonstrated. Considering that nitric oxide synthases (NOS) and arginases compete for the same substrate, it is worthwhile to elucidate the effects of complex NOS-arginase dysfunction in the pathophysiology of asthma, particularly, related to distal lung tissue. We evaluated the effects of arginase and iNOS inhibition on distal lung mechanics and oxidative stress pathway activation in a model of chronic pulmonary allergic inflammation in guinea pigs.

Methods: Guinea pigs were exposed to repeated ovalbumin inhalations (twice a week for 4 weeks). The animals received $1400 \mathrm{~W}$ (an iNOS-specific inhibitor) for 4 days beginning at the last inhalation. Afterwards, the animals were anesthetized and exsanguinated; then, a slice of the distal lung was evaluated by oscillatory mechanics, and an arginase inhibitor (nor-NOHA) or vehicle was infused in a Krebs solution bath. Tissue resistance (Rt) and elastance (Et) were assessed before and after ovalbumin challenge (0.1\%), and lung strips were submitted to histopathological studies.

Results: Ovalbumin-exposed animals presented an increase in the maximal Rt and Et responses after antigen challenge $(p<0.001)$, in the number of iNOS positive cells $(p<0.001)$ and in the expression of arginase $2,8-$ isoprostane and NF-kB $(p<0.001)$ in distal lung tissue. The $1400 \mathrm{~W}$ administration reduced all these responses $(p<0.001)$ in alveolar septa. Ovalbumin-exposed animals that received nor-NOHA had a reduction of Rt, Et after antigen challenge, iNOS positive cells and 8-isoprostane and NF-kB $(p<0.001)$ in lung tissue. The activity of arginase 2 was reduced only in the groups treated with nor-NOHA $(p<0.05)$. There was a reduction of 8 -isoprostane expression in OVA-NOR-W compared to OVA-NOR $(p<0.001)$.

(Continued on next page)
\end{abstract}

\footnotetext{
*Correspondence: laristoteles@hotmail.com; iocalvo@uol.com.br

'Department of Clinical Medicine, School of Medicine, University of Sao

Paulo, 01246-903 São Paulo, SP, Brazil

${ }^{4}$ Faculty of Medicine, University of São Paulo, Av. Dr. Arnaldo, 455 - Sala

1210, 01246-903 São Paulo, SP, Brazil

Full list of author information is available at the end of the article
} 
(Continued from previous page)

Conclusions: In this experimental model, increased arginase content and iNOS-positive cells were associated with the constriction of distal lung parenchyma. This functional alteration may be due to a high expression of 8-isoprostane, which had a procontractile effect. The mechanism involved in this response is likely related to the modulation of NF-kB expression, which contributed to the activation of the arginase and iNOS pathways. The association of both inhibitors potentiated the reduction of 8-isoprostane expression in this animal model.

Keywords: Lung parenchyma, Arginase, iNOS, Nitric oxide, Guinea-pig, nor-NOHA, Oxidative stress

\section{Background}

Asthma is a disease of both the airways and, as recently addressed, the alveolar parenchyma. Some studies have demonstrated the presence of inflammation and the remodeling of lung parenchyma in asthma, both in humans and in experimental models, showing the relevance of distal lung tissue responses in total pulmonary resistance and the effects of inflammatory mediators in peripheral lung changes [1-9].

Nitric oxide (NO) is an important endogenous modulator of airway and distal lung constriction, generated by a family of NO synthase (NOS) isoforms. Studies in macrophages have indicated that under conditions of low Larginine availability, iNOS not only produces $\mathrm{NO}$ via its oxygenase moiety, but its reductase moiety also synthesizes superoxide anions, leading to the efficient formation of peroxynitrite [10]. Subsequently, isoprostane generation may result from lipid peroxidation induced by peroxynitrite formation. PGF2 $\alpha$ represents the main member of the isoprostane family, which members are biochemical markers of oxidative stress and are produced through the peroxidation of arachidonic acid [10-12].

Airway inflammation is accompanied by a marked upregulation of iNOS expression, particularly in airway epithelium [13], that has been associated with the activation of nuclear factor-kB (NF-kB) that play critical roles in inflammation, immunity, cell proliferation, differentiation and survival [14]. Further studies showed that NF$\mathrm{kB}$ is activated in the lung tissue of animal models of allergic airway inflammation [15] and of patients with asthma [16], specifically within airway epithelium, and it is known that NF- $\mathrm{KB}$ activity can be affected by reactive oxygen species (ROS) as well as reactive nitrogen species (RNS) [17].

Arginases, which convert L-arginine into L-ornithine and urea, are key enzymes of the urea cycle in the liver (arginase 1) but are also expressed in cells and tissues that lack a complete urea cycle, for example, arginase 2 expression in the lung [18].

Que et al. [19] demonstrated the expression of arginase in the bronchial epithelium and in peribronchial connective tissue fibroblasts. In addition, Meurs et al. [18] showed that arginase appears to modulate the tone of airway smooth muscle and potentiates methacholine- induced airway constriction. Arginase accomplishes this by competing the common substrate L-arginine away from epithelial cNOS to diminish agonist-induced $\mathrm{NO}$ production. Arginases and NOS compete for the bioavailability of the same substrate, L-arginine, and are involved indirectly in the regulation of NO synthesis [20].

Several powerful drugs have been used to investigate the role of arginase in the pathophysiology of asthma, including nor-NOHA ( $\mathrm{N} \omega$-hydroxy-nor-Larginine), which is one of the most potent inhibitors of arginase [21]. Meurs et al. [22], studying in vitro tracheal ring of sensitized guinea pigs, demonstrated that treatment with nor-NOHA reduced hyperresponsiveness to methacholine, and this effect was reversed by treatment with L-NAME.

Previously, we had used guinea pigs with chronic allergic inflammation treated with a false substrate for all NOS (L-NAME) and a specific iNOS inhibitor (1400 W) to demonstrate that all NOS constitutive isoforms reduced lung responsiveness and inflammatory response and protected against extracellular matrix remodeling. Moreover, NO derived from iNOS activation contributes to increased lung responsiveness, inflammatory cells recruitment and extracellular matrix remodeling both in airways and distal lung parenchyma [2,3,5-7].

Considering these complex interactions, we hypothesis that, increased arginase activity 2 also plays a key role in the pathophysiology of chronic asthma. In order to clarify this statement we evaluated the expression and activity of arginase 2 as well by treatment with a specific inhibitor of arginase (Nu-hydroxy-or L-arginine: norNOHA) attenuates mechanical oscillatory responses and oxidative stress of lung tissue in a distal model chronic allergic pulmonary inflammation.

\section{Methods}

Male guinea pigs received humane care in compliance with the "Guide for the care and use of laboratory animals" (NIH publication 85-23, revised 1985), and experiments described in this study were previously approved by the Institutional Review Board of the University of São Paulo.

\section{Induction of chronic pulmonary allergic inflammation} Male Hartley guinea pigs weighing 300-400 g were placed in a plexiglass box $(30 \times 15 \times 20 \mathrm{~cm})$ coupled to 
an ultrasonic nebulizer (Soniclear, São Paulo, Brazil). A solution of ovalbumin (OVA, Grade V, Sigma Chemical Co., Saint Louis, MO, USA) diluted in $0.9 \% \mathrm{NaCl}$ (normal saline) was prepared. For four weeks, the animals received seven inhalations of increasing concentrations of OVA $(1 \sim 5 \mathrm{mg} / \mathrm{mL})$ to counteract tolerance (Figure 1$)$. Control animals received aerosolized normal saline (SAL group). The solution was continuously aerosolized into the environment until respiratory distress occurred, as previously described $[4,6,23]$. The observer who made the decision to withdraw the guinea pig from the inhalation box was blinded to the treatment status of the animal.

\section{W administration}

1400 W (Tocris Bioscience, Ellisville, MO, USA) (a specific and highly selective iNOS-inhibitor) was given ip for four days at $2 \mathrm{mg} / \mathrm{kg} / \mathrm{animal} /$ day (OVA-W group), beginning 30 minutes before the $7^{\text {th }}$ inhalation of either ovalbumin or normal saline. This approach was chosen based on previous data $[6,24,25]$. As high doses of $1400 \mathrm{~W}(50 \mathrm{mg} /$ $\mathrm{kg}$ ip) can cause toxic effects, we chose a lower dose with previously demonstrated proven therapeutic efficacy in experimental models $[7,25]$.

\section{nor-NOHA administration}

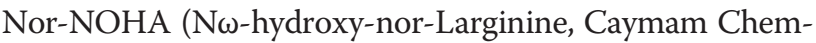
ical, Ellsworth Road Ann Arbor, MI, USA) is considered one of the most potent inhibitors of arginase, as previously described [22]. At the beginning of the protocol norNOHA $(10 \mu \mathrm{M})$ was added to the Krebs bath and after 40 minutes we performed OVA (0.1\%) challenge. Afterwards, mechanical evaluation was done.

\section{Experimental groups}

The animals were randomly divided into the following experimental groups ( $n=6$ for each group):

a) Inhalations with sterile saline $0.9 \%$ (SAL group);

b) Inhalations with ovalbumin solution (OVA group);

c) Inhalations with ovalbumin solution and treatment with nor-NOHA in the bath (OVA-NOR group);

d) Inhalations with ovalbumin and treatment with $1400 \mathrm{~W}$ (ip) (OVA-W group);

e) Inhalations with ovalbumin solution and $1400 \mathrm{~W}$ (ip) and nor-NOHA in the bath (OVA-NOR-W group).

\section{Oscillatory mechanics measurements}

Seventy-two hours after the $7^{\text {th }}$ inhalation, the animals were anesthetized with thiopental $(50 \mathrm{mg} / \mathrm{Kg}$ (ip), tracheostomized, and exsanguinated after thoracotomy. Heart and lungs were excised en bloc, and the lungs were infused with Krebs solution (in $\mathrm{mM}: \mathrm{NaCl}, 118$; $\mathrm{KCl}, 4.5 ; \mathrm{NaHCO}_{3}, 25.5 ; \mathrm{CaCl}_{2}, 2.5 ; \mathrm{MgSO}_{4}, 1.2 ; \mathrm{KH}_{2} \mathrm{PO}_{4}$, 1.2; glucose 10; all from Sigma Chemical). Sagittal slices of both lungs (defined herein as total lung) were covered with Optimum Cutting Temperature (OCT) compound (Reichert-Jung, Heidelberg, Germany) and cooled in liquid nitrogen for subsequent histopathological studies. Subpleural parenchyma strips of the lower lobes $(10 \mathrm{~mm} \times 2 \mathrm{~mm} \times 2 \mathrm{~mm})$ were cut, and the resting length (Lr) and wet weight (W0) of each strip were measured. Metal clips were glued to either end of the tissue strips with cyanoacrylate. Steel wires $(0.5-\mathrm{mm}$ diameter) were attached to the clips; one side was connected to a force transducer (model 404A; Cambridge Technologies, Ontario, Canada), and the other side was connected to a

Protocol for chronic pulmonary allergic inflammation

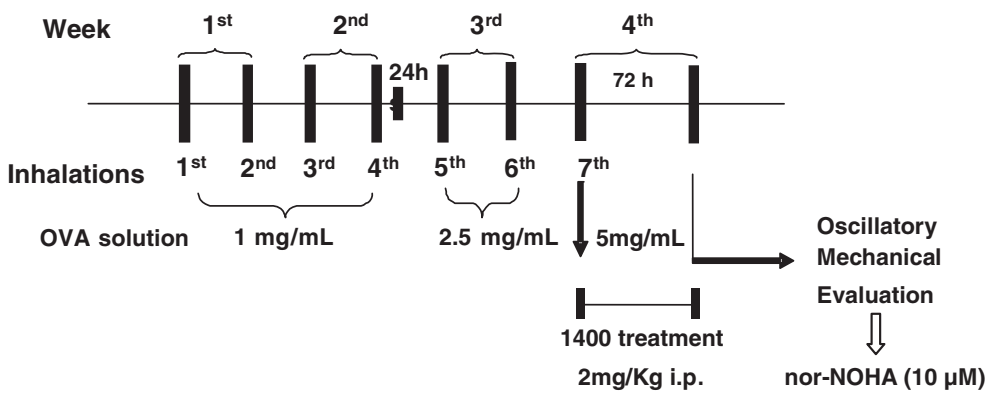

Figure 1 Timeline of the experimental protocol. The guinea pigs underwent 7 inhalations (2 per week with 2- to 3-day intervals over 4 weeks) with aerosols of normal saline or ovalbumin solution and increasing doses of antigen. For the $1^{\text {st }}$ through the $4^{\text {th }}$ inhalations, the dose used was $1 \mathrm{mg} / \mathrm{mL}$ of ovalbumin ( 2 weeks). In the $5^{\text {th }}$ and $6^{\text {th }}$ inhalations ( $3^{\text {rd }}$ week), the animals inhaled $2.5 \mathrm{mg} / \mathrm{mL}$ of ovalbumin, and for the $7^{\text {th }}$ inhalation (beginning in the $4^{\text {th }}$ week) $5 \mathrm{mg} / \mathrm{mL}$ of antigen was used. Treatment with $1400 \mathrm{~W}$ started 30 minutes before the $7^{\text {th }}$ inhalation and was given daily until the oscillatory mechanics assessment. The solution of ovalbumin or normal saline was continuously aerosolized for 15 minutes or until respiratory distress occurred. Seventy-two hours after the $7^{\text {th }}$ inhalation, the animals were anesthetized, exsanguinated, and their lungs were removed for oscillatory mechanics measurement. Nor-NOHA (10 $\mu \mathrm{M})$ was infused in the bath during the evaluation of oscillatory mechanics. 
servo-controlled lever arm (model 300B; Cambridge Technologies). The lever arm was capable of peak-to-peak length excursions of $8 \mathrm{~mm}$ and length resolutions of $1 \mu \mathrm{m}$. It was connected to a function generator (model 3030; BK Precision, Chicago, IL, USA), which controlled the frequency, amplitude, and waveform of the oscillation.

The resting tension $(\mathrm{T})$ was set by the movement of a screw thumb wheel system, which effected slow vertical displacements of the force transducer. Length and force signals were converted from analog to digital with an analog-to-digital converter and recorded by a compatible computer. The strips were preconditioned three times by slowly cycling tension from 0 to $2 \mathrm{~g}$. After the third cycle, they were fixed at $1 \mathrm{~g}$ [8] and maintained in an organ bath containing aerated Krebs solution (95\% of $\mathrm{O}_{2}$, $5 \%$ of $\mathrm{CO}_{2}$ ), which was changed every 15 minutes for 50 min to allow stress relaxation. The frequency of oscillation was $1 \mathrm{~Hz}$ and the amplitude was 2.5\% Lr [8]. Baseline measurements of tissue resistance $(\mathrm{Rt})$ and elastance $(\mathrm{Et})$ were obtained for $5 \mathrm{~min}$, and then the maximal responses of $\mathrm{R}$ and $\mathrm{E}$ were collected $10 \mathrm{~min}$ after a specific antigen challenge with OVA (0.1\%) in the bath [26]. The R and E were estimated by the recursive least-squares algorithm to the equation of motion [27].

$$
\mathrm{T}=\mathrm{E} \Delta \mathrm{l}+\mathrm{R}(\Delta \mathrm{l} / \Delta \mathrm{t})+\mathrm{K}
$$

where $\mathrm{T}$ is tension, $\mathrm{l}$ is length, $\Delta \mathrm{l} / \Delta \mathrm{t}$ is the length change per unit of time, and $\mathrm{K}$ is a constant reflecting resting tension. The results were standardized for strip size. The unstressed cross-sectional area $\left(A_{0}\right)$ of the strip was obtained from the formula:

$$
\mathrm{AO}\left(\mathrm{cm}^{2}\right)=\mathrm{W} 0 /(\mathrm{p} \times \mathrm{Lr})
$$

where $\mathrm{p}$ is the mass density of the tissue taken as $1.06 \mathrm{~g} /$ $\mathrm{cm}^{3}$, W0 is the wet weight in grams, and $L_{\mathrm{r}}$ is the resting length in centimeters. The values of $\mathrm{R}$ and $\mathrm{E}$ were multiplied by $L_{\mathrm{r}} / A_{0}$. We analyzed the percentage of increase in resistance $(\% \mathrm{R})$ and elastance $(\% \mathrm{E})$ in relation to the baseline [8]. Afterwards, the strips were fixed in $10 \%$ formalin for 48 (hours) and embedded in paraffin for histological analysis.

\section{Morphometric analysis}

The homogeneity of the strip samples was assured by measuring the fractional area of tissue constituents with the point-counting method [3,28,29] using a 100-point grid with a known area $(62,500 \mu \mathrm{m}$ at $400 \times$ magnification) attached to the ocular of the microscope. We measured the fractional area of bronchial wall (BW), blood vessel wall (BVW), and alveolar wall (AW) as the number of points that fell in either BW, BVW or AW divided by the total number of points that fell in the strip tissue. Measurements were performed in 10 fields per slide at
$400 \times$ magnification. We have calculated the mean values for each animal. The morphometric analysis was performed by two authors blinded to the experimental groups. The variability of these measurements observed was $1 \%$ (coefficient of variation).

\section{Measurement of iNOS positive cells}

The total lung slices covered with OCT and cooled in liquid nitrogen were used for the detection of iNOS positive cells. The cryostat sections (Leica CM1850; Leica, Nosfloch, Germany) were mounted on glass slides precoated with aminopropyltriethoxysilane (Sigma Chemical Co.) and fixed in chloroform-acetone (Merck, Rio de Janeiro, Brazil) vol/vol for 10 minutes at room temperature. Immunohistochemistry analysis was performed as previously described [6]. The sections were then incubated for 30 minutes at room temperature with a blocking solution containing normal mouse serum (Dako Corp., Carpinteria, CA, USA).

Monoclonal antisera raised in mouse against iNOS (IgG2a - iNOS/NOS Type II - N32020 - BD Transduction Laboratories, San Diego, CA, USA) [6,7,30] were used as the primary antisera (incubation overnight at room temperature, 1:5 dilution in Tris buffer). After three 5-minute washes in tris-buffered saline (TBS), the sections were incubated with a secondary antibody (LSAB+AP Link Universal, Dako Corp.) for 30 minutes at $37^{\circ} \mathrm{C}$ in a humid chamber. The slides were given three more 5-minute washes in TBS and were coverslipped with pre-diluted (for 30 minutes) alkaline phosphatase (LSAB + AP - Streptavidin AP - Dako Corp.). This was followed by incubation with the substrate Fast Red TR (Sigma Chemical Co.) for 6 minutes and light hematoxylin counterstaining for 1 minute. Ten fields were analyzed per lung at a magnification of $1000 \times$ in an optical microscope $\left(10^{4} \mu \mathrm{m}^{2}\right)$. The iNOS positive cells were expressed as number of cells $/ 10^{4} \mu \mathrm{m}^{2}[6,7]$.

\section{Evaluation of NF-kB expression}

The immunohistochemistry analysis was carried out using biotin-streptavidin peroxidase. Histological sections $3 \mu \mathrm{m}$ thick were made on silanized slides (3-Aminopropyltrietoxy-silane-Sigma) and the protocol described below was followed. The slides were dewaxed, hydrated and the endogenous peroxidase was blocked with hydrogen peroxide $\left(3 \% \mathrm{H}_{2} \mathrm{O}_{2}\right)$ 10V 7 times for 5 minutes each, after which the slides were washed with water and PBS. Antigen retrieval was performed in a pressure cooker (Pascal) for 1 minute at $125^{\circ} \mathrm{C}$ with citrate buffer $\mathrm{pH}$ : 6.0. After blocking, the primary NF-kB antibody (cod. SC-109, Santa Cruz Biotechnology, USA, CA), was diluted in BSA 1:50, applied to the slides and incubated overnight. The slides were then washed in PBS and incubated with secondary antibody (1 hour) and complex (30 min) by ABCKit Vectastain 
(Vector Elite PK-6101 (anti-Rabbit) in an oven at $37^{\circ} \mathrm{C}$. After this step, the slides were washed in PBS and the antibody staining visualized through the addition of 3.3 chromogen diaminobenzidine (DAB - Dako K 3466). The slides were washed thoroughly with tap water and counterstained with Harris hematoxylin (Merck, Darmstadt, Germany). The slides were then washed in water, dehydrated, cleared and mounted with Entellan resin (Merck, Darmstadt, Germany). The NF-kB expression was evaluated under $\times 400$ magnification with an ImagePro Plus 4.5 v Image Analysis System [6,7], and the results were obtained as a relationship between the quantity of NF- $\mathrm{kB}$ expression in a specific frame and the total area of the frame expressed as a percentage.

\section{Evaluation of PGF2a expression}

Immunohistochemical staining was performed using an antibody against anti-8-iso-PGF2 $\alpha$ (Oxford Biomedical Research, Rochester Hills, MI, USA) at a 1:500 dilution. The sections were deparaffinized and washed 7 times for 5 minutes with $\mathrm{H}_{2} \mathrm{O}_{2} 10 \mathrm{~V} 3 \%$ to inhibit endogenous peroxidase activity. After washes in PBS and water, the antigen retrieval was performed with trypsin for 20 minutes. Afterwards, 3 washes in PBS were performed for 3 minutes each. The sections were incubated with anti-8-epi-PGF2 diluted in BSA overnight. After washes in PBS, ABCKit Vectastain (Vector Elite PK-6105, Burlingame, CA) was used as the secondary antibody and 3,3 Diaminobenzidine (DAB) (Sigma Chemical Co) was used as the chromogen. The sections were counterstained with Harris hematoxylin (Merck) [31]. The PGF2 $\alpha$ content was evaluated as described in the section: Evaluation of NF-kB expression.

\section{Arginase 2 expression}

The arginase 2 antibody was evaluated with biotinstreptavidin peroxidase. Histological sections $3 \mu \mathrm{m}$ thick were made on silanized (3-Aminopropyl-trietoxy-silaneSigma) slides. The sections were deparaffinized and hydrated, and the endogenous peroxidase was then blocked with $3 \%$ hydrogen peroxide $\left(\mathrm{H}_{2} \mathrm{O}_{2}\right) 7$ times for 5 minutes each, followed by washes with water and PBS. After blocking, a primary antibody against arginase 2 (cod. 18357, Santa Cruz Biotechnology, USA, CA) was diluted in BSA at 1:120 and incubated on the slides overnight. The sections were then washed in PBS and incubated with the secondary antibody (1 hour) and complex (30 min) using ABCKit Vectastain Vector Elite PK-6105 (anti-Goat) in a 37 degree oven. After this step, the sections were washed in PBS and visualized with 3.3 chromogen diaminobenzidine (DAB - Dako K 3466). The sections were then washed thoroughly with tap water and counterstained with Harris hematoxylin (Merck, Darmstadt, Germany). Finally, the sections were washed in water, dehydrated, cleared and mounted with Entellan resin for microscopy (Merck, Darmstadt, Germany). The arginase content was evaluated as described in the section: Evaluation of NF-kB expression.

\section{Arginase $\mathbf{2}$ activity}

After extraction, samples were immediately frozen in liquid nitrogen and stored at $-80^{\circ} \mathrm{C}$ until homogenization. Subpleural parenchyma strips were homogenized in an extraction buffer (20 mM Tris ( $\mathrm{pH} 7.4), 2 \mathrm{uM}$ phenylmethanesulfonylfluoride (PMSF)) with a Polytron PTA $20 S$ generator (model PT 10/35, Brinkmann Instruments, Inc., Westbury, NY, USA) operated at maximum speed for $30 \mathrm{sec}$. The extracts were centrifuged at $15,000 \mathrm{~g}, 4^{\circ} \mathrm{C}$, for $30 \mathrm{~min}$ to remove insoluble material. Protein concentrations of the supernatants were determined by the Bradford assay. QuantiChrom ${ }^{\text {тм }}$ Arginase Assay Kit (DARG-200, Bioassay Systems, Hayward, CA, USA) was used to assess the activity of arginase. In short, $40 \mu \mathrm{l}$ of homogenate was plated into a 96-well plate and $10 \mu \mathrm{l}$ of $5 \times$ substrate buffer (4 vol of Arginine Buffer and 1 vol of the Mn Solution, supplied in the kit) subsequently added. The controls consisted of $40 \mu \mathrm{l}$ of homogenate without substrate buffer $5 \times$. The plate was incubated at $37^{\circ} \mathrm{C}$ for 2 hours. To stop the reaction, $200 \mu \mathrm{l}$ of urea reagent, supplied in the kit, was added to each well and also $10 \mu$ l of $5 \times$ substrate buffer to control samples. Plate was incubated for $60 \mathrm{mi}$ nutes at room temperature. The reading was performed at $430 \mathrm{~nm}$ and the activity of arginase 2 was calculated by measuring the reaction rate. One unit (U) of arginase converts 1 umol of L-arginine to ornithine and urea per minute at $\mathrm{pH} 9.5$ and $37^{\circ} \mathrm{C}$. The specific activity was then expressed in terms of activity per milligram of protein $(\mathrm{mU} / \mathrm{mg})$.

\section{Data analysis}

Values were expressed as medians and percentiles and graphics were performed as "Box plot". The data were examined using Kruskal-Wallis non-parametric analysis of variance. Multiple comparisons were made using Dunn's test. A $p$ value $<0.05$ was considered significant [32]. We also obtained a Spearman correlation coefficient (R) to assess the associations of the Rt scores with the NF-kB, iNOS, isoprostane, PGF2 $\alpha$ and arginase 2 expression. A $p$ value $<0.05$ was considered significant [32].

\section{Results}

Values were expressed as medians and percentiles [Median (25-75\%)]

Inhibition of iNOS or Arginase 2 attenuates oscillatory mechanics in sensitized animals

The ovalbumin-exposed animals (OVA group) presented an increase in the \%Rt [85.0 (69.6-144.0)] and \%Et [63.6 (62.1-111.8)] after OVA challenge relative to the salineexposed ones (SAL group) (\%Rt: [9.0 (3.5-18.0)] and \%Et: 
[5.7 (1.3-11.1)] $(\mathrm{p}<0.001$ for all comparisons). In the sensitized animals, the nor-NOHA group (OVA-NOR group) had lower \%Rt [23.2 (4.5-35.8)] and \%Et [18.2 (4.8-25.7)] than the ovalbumin-exposed (OVA group) or the vehicletreated animals $(\mathrm{p}<0.001)$. The $1400 \mathrm{~W}$ administration in ovalbumin-exposed animals (OVA-W group) reduced the \%Rt [43.1 (17.0-70.8)] and \%Et [33.8 (11.6-57.1)] compared to ovalbumin-exposed (OVA group) and vehicletreated animals $(\mathrm{p}<0.001)$. In sensitized GP, nor-NOHA and $1400 \mathrm{~W}$ administration in ovalbumin-exposed animals (OVA-NOR-W group) reduced the \%Rt [41.0 (31.567.0)] and \%Et [32.4 (16.4-50.9)] below values observed in the OVA group $(\mathrm{p}<0.001)$. However, there were no differences between the OVA-NOR and OVA-NOR-W groups (Figure $2 \mathrm{~A}$ and $\mathrm{B}$ ).

\section{Inhibition of iNOS or Arginase 2 attenuates arginase 2 expression and activity, the number of iNOS positive cells and NF-kB expression}

There was an increase in the arginase 2 expression (Figure 3) in the ovalbumin-exposed animals (OVA group) compared to the saline-exposed ones (SAL group) [16.0 (13.7-22.7)] and [8.2 (1.8-13.4) \%, respectively, $\mathrm{p}<0.001]$. The ovalbumin-exposed animals that received nor-NOHA (OVA-NOR) [10.2 (6.2-13.4) \%] and the ovalbumin-exposed animals that received $1400 \mathrm{~W}$ treatment and nor-NOHA (OVA-NOR-W) [5.1 (2.4-10.3) \%] had lower arginase expression than the ovalbuminexposed animals (OVA group) $(\mathrm{p}<0.001)$. The ovalbuminexposed animals that received 1400W treatment and nor-NOHA (OVA-NOR-W group) had lower arginase expression in lung tissue than the OVA-W animals [12.8 (6.7-16.0) \%, p<0.001]. However, there were no differences between the OVA-NOR and OVA-NOR-W groups.

There was an increase in arginase 2 activity (Figure 4) in ovalbumin-exposed animals (OVA group) relative to the saline-exposed animals (SAL group) [8.8 (7.0-10.8) $\mathrm{mU} / \mathrm{mg}]$ and $\left[\begin{array}{ll}4.9 & (4.7-5.2) \mathrm{mU} / \mathrm{mg}\end{array}\right]$ respectively, $\mathrm{p}<0.001)$. The ovalbumin-exposed animals that received nor-NOHA (OVA-NOR) had lower arginase 2 activity [3.6 (3.3-4.9) $\mathrm{mU} / \mathrm{mg}$ ] than the ovalbumin exposed animals (OVA group) $(\mathrm{p}<0.05)$. The ovalbumin-exposed animals that received both $1400 \mathrm{~W}$ treatment and norNOHA (OVA-NOR-W group) had lower arginase expression in lung tissue than the OVA-W animals [3.4 (2.4-4.3) $\mathrm{mU} / \mathrm{mg}$ ] and [8.6 (4.4-11.5) $\mathrm{mU} / \mathrm{mg}$, respectively $\mathrm{p}<0.05]$. Nevertheless, there were no differences between the OVA-NOR and OVA-NOR-W groups.

The ovalbumin-exposed animals (OVA group) showed an increase in the number of iNOS positive cells (Figure 5) in the alveolar septum [29.8 (19.3-49.2) cells $\left./ 10^{4} \mu \mathrm{m}^{2}\right]$ compared to the animals exposed to saline (SAL group) [6.4 (3.8-9.2) cells $\left./ 10^{4} \mu \mathrm{m}^{2}\right]$. The ovalbumin-exposed animals that received nor-NOHA (OVA-NOR) showed a

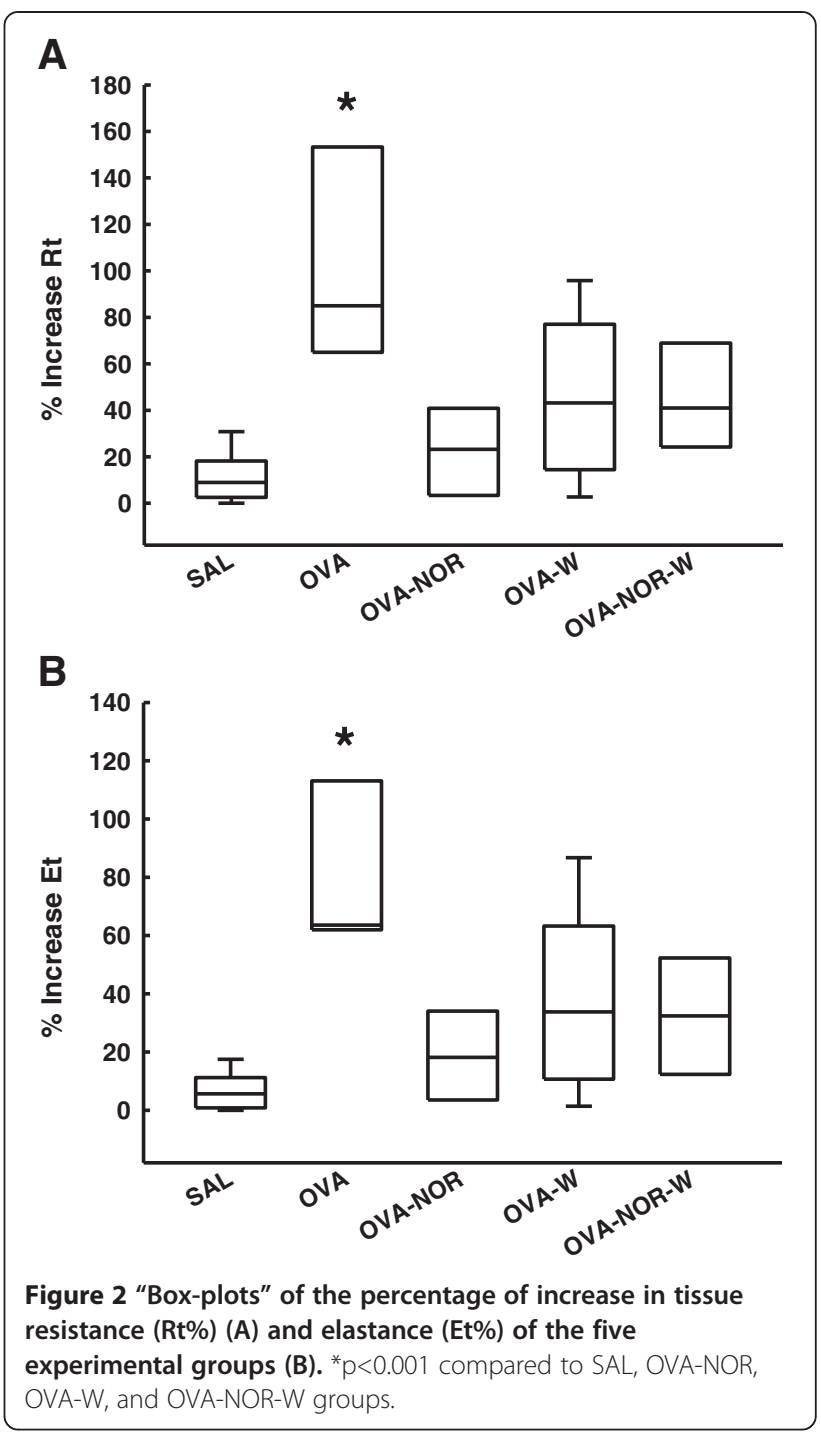

lower number of iNOS positive cells [9.1 (6.1-14.7) cells/ $10^{4} \mu^{2}$ ] than the ovalbumin exposed ones (OVA group) $(\mathrm{p}<0.001$. The ovalbumin-exposed animals that received $1400 \mathrm{~W}$ and nor-NOHA (OVA-NOR-W group) had a lower amount of iNOS positive cells in their lung tissue than the OVA-W animals [11.7 (9.0-15.1)] and [27.5 $(17.8-37.8)$ cells $/ 10^{4} \mu \mathrm{m}^{2}$, respectively $\left.\mathrm{p}<0.001\right]$. However, there were no differences between the OVA-NOR and OVA-NOR-W groups.

Ovalbumin-exposed animals (OVA group) showed an increase in NF-kB expression (Figure 6) in the alveolar septum [14.8 (13.3-16.3) \%] compared to the animals exposed to saline (SAL group) [5.5 (4.5-7.5) \%]. The ovalbumin-exposed animals that received nor-NOHA (OVA-NOR) showed less NF-kB expression [6.8 (0.9-9.8) \%] than the ovalbumin exposed animals (OVA group) $(\mathrm{p}<0.001)$. Treatment with $1400 \mathrm{~W}$ diminished the NF-kB expression in the sensitized animals (OVA-W group) 


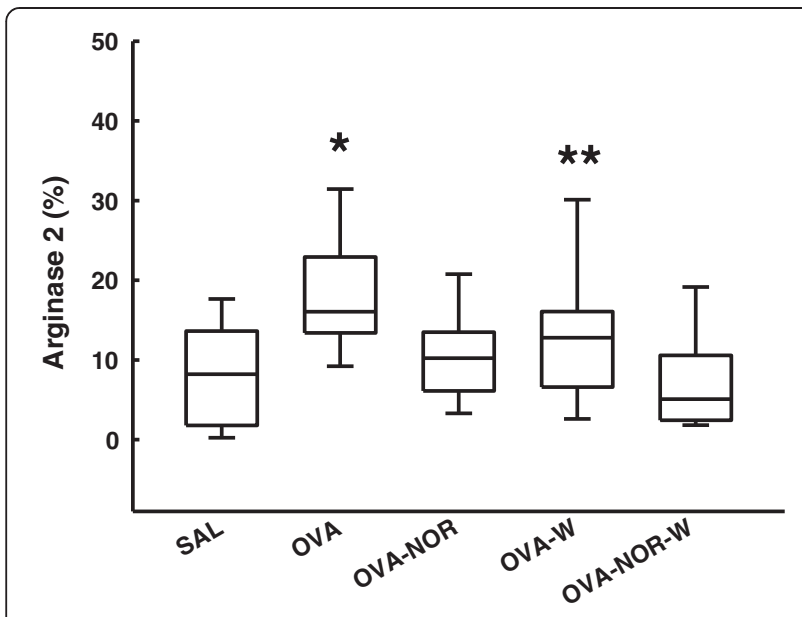

Figure 3 "Box-plots" of arginase 2 expression (\%) in the alveolar septa of the five experimental groups. ${ }^{*} p<0.001$ compared to SAL, OVA-NOR, OVA-W, and OVA-NOR-W groups. ${ }^{* *} \mathrm{p}<0.001$ compared to OVA-NOR-W group.

compared to the ovalbumin exposed ones $(\mathrm{p}<0.001)$. The ovalbumin-exposed animals that received both $1400 \mathrm{~W}$ and nor-NOHA (OVA-NOR-W group) showed a lower expression of NF-kB in lung tissue than the OVA-W animals [4.2 (1.7-6.3) \%] and [13.0 (11.1-14.1) \%, respectively, $\mathrm{p}<0.001]$. However, there were no differences between the OVA-NOR and OVA-NOR-W groups.

\section{The association of iNOS and Arginase 2 inhibition} potentates the reduction of isoprostane PGF2a expression We observed an increased expression of PGF2 $\alpha$ (Figure 7) in the alveolar septum of guinea pigs exposed to ovalbumin (OVA group) [9.4 (5.0-14.3) \%] compared with those

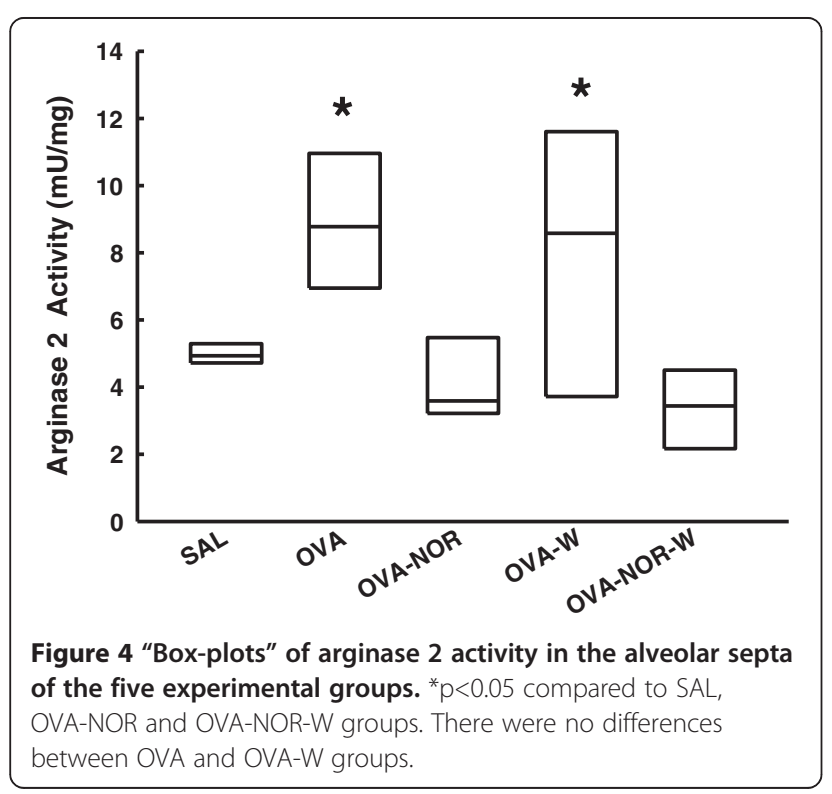

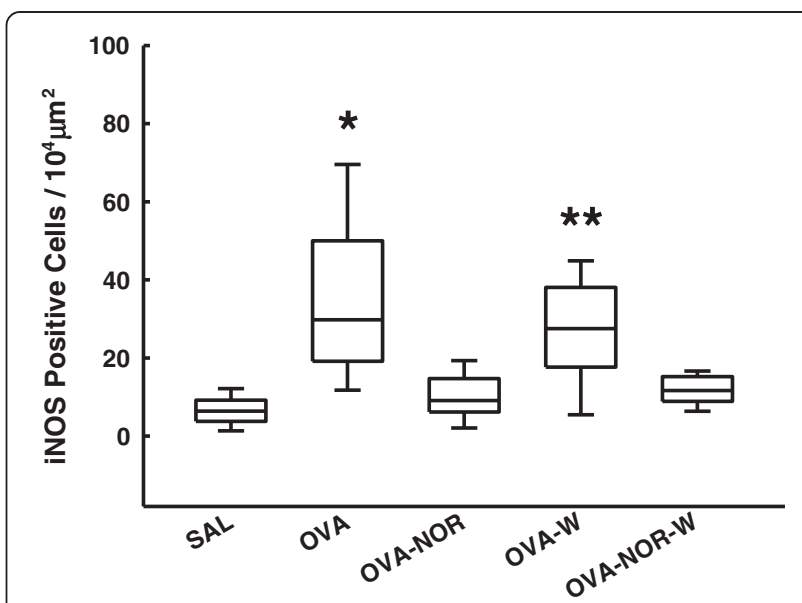

Figure 5 "Box-plots" of iNOS-positive cells in the alveolar septa of the five experimental groups. ${ }^{*} p<0.001$ compared to the SAL, OVA-NOR, and OVA-NOR-W groups. ${ }^{* *} p<0.001$ compared to OVA-NOR-W group.

exposed only to saline (SAL group) [3.5 (1.6-5.5) \%], to that ovalbumin-exposed animals that received nor-NOHA (OVA-NOR group) [4.7 (2.2-7.1) \%] to that ones that received $1400 \mathrm{~W}$ (OVA-W group) [2.1 (0.0-4.8) \%] and to that ovalbumin-exposed animals that received $1400 \mathrm{~W}$ and nor-NOHA (OVA-NOR-W group) [0.1 (0.0-0.2) \%] ( $<<0.001$ for all comparisons). The ovalbumin-exposed animals that received $1400 \mathrm{~W}(\mathrm{OVA}-\mathrm{W})$ showed a lower expression of PGF2 $\alpha$ in the alveolar septum than the OVA-NOR animals. There was a significant reduction of PGF $2 \alpha$ in the alveolar septum in the OVA-NOR-W group compared to the SAL, OVA-NOR and OVA-W groups $(\mathrm{p}<0.001)$.

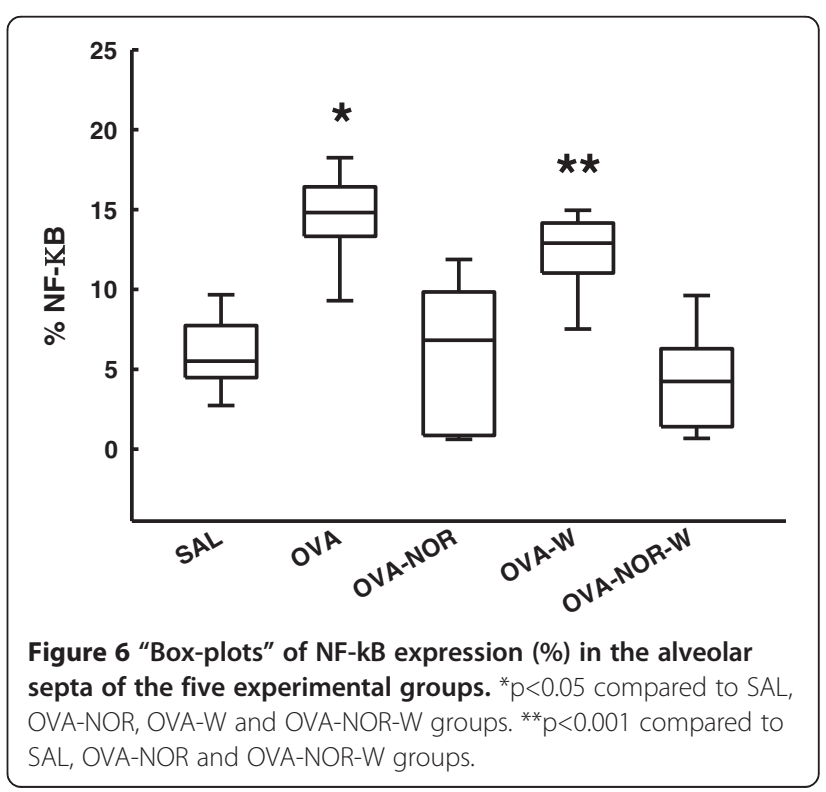




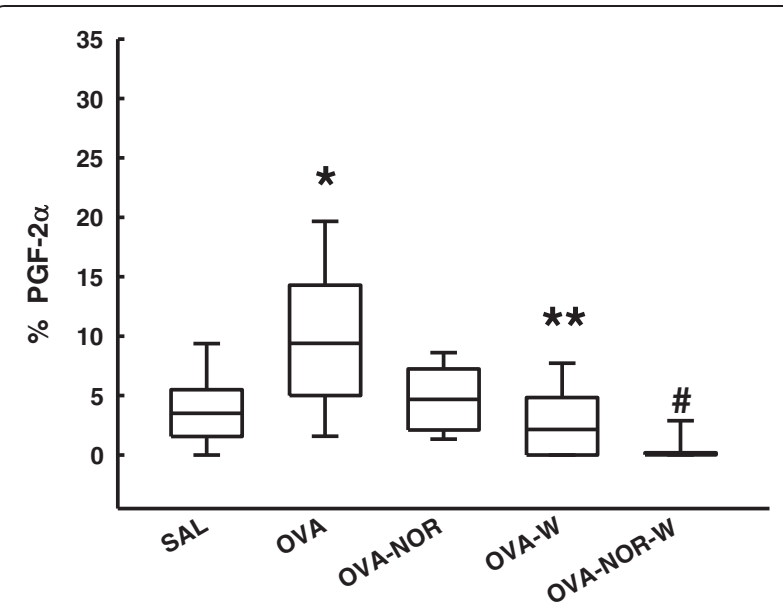

Figure 7 "Box-plots" of PGF2a expression (\%) in the alveolar septa of the five experimental groups. ${ }^{*} p<0.001$ compared to SAL, OVA-NOR, OVA-W and OVA-NOR-W groups. ${ }^{* *} \mathrm{p}<0.001$ compared to OVA-NOR group. ${ }^{\#} \mathrm{p}<0.001$ compared to SAL and OVA-NOR.

Correlation of arginase 2, Isoprostane PGF2a, iNOS, NF-kB with distal lung mechanics

In order to better understand all the results and the mechanisms involved, we also performed an analysis of correlation among the functional parameters and the histopathologycal findings. We observed a positive and correlation between $\mathrm{Rt}$ with NF-kB expression ( $\mathrm{R}=0.5$ and $\mathrm{p}<0.002)$; with iNOS positive cells $(\mathrm{R}=0.762$ and $\mathrm{p}<0.001)$; Isoprostane PGF $2 \alpha(\mathrm{R}=0.375$ and $\mathrm{p}<0.05)$ and arginase 2 expression $(\mathrm{R}=0.569$ and $\mathrm{p}<0.001)$ (Table 1$)$. In addition, we observed a positive and correlation between NF-kB expression with iNOS positive cells $(R=0.573$ and $\mathrm{p}<0.01)$ and arginase 2 expression $(\mathrm{R}=0.548$ and $\mathrm{p}<0.01)$ (Table 1).

\section{Descriptive analysis}

The control group (SAL group) showed low amounts of arginase 2 , iNOS positive cells, NF-kB and PGF $2 \alpha$ content

Table 1 Spearman correlation: arginase 2, Isoprostane PGF2 $a$, iNOS, NF-kB, \%Et and \%Rt

\begin{tabular}{|c|c|c|c|c|c|c|}
\hline & & Isoprostane & iNOS & NF-kB & $\% R t$ & $\% E t$ \\
\hline \multirow[t]{2}{*}{ Arginase 2} & $\mathrm{R}$ & 0.508 & 0.519 & 0.548 & 0.569 & 0.0847 \\
\hline & $p$ & 0.00367 & 0.00293 & 0.00150 & 0.000909 & 0.648 \\
\hline \multirow{2}{*}{$\begin{array}{l}\text { Isoprostane } \\
\text { PGF2a }\end{array}$} & $\mathrm{R}$ & & 0.121 & 0.365 & 0.375 & 0.0434 \\
\hline & $\bar{p}$ & & 0.512 & 0.0433 & 0.0379 & 0.814 \\
\hline \multirow[t]{2}{*}{ iNOS } & $\mathrm{R}$ & & & 0.573 & 0.762 & 0.220 \\
\hline & $\bar{p}$ & & & 0.000810 & 0.000000200 & 0.232 \\
\hline \multirow[t]{2}{*}{ NF-kB } & $\mathrm{R}$ & & & & 0.533 & 0.443 \\
\hline & $\bar{p}$ & & & & 0.00216 & 0.0129 \\
\hline
\end{tabular}

$\mathrm{R}=$ Correlation Coefficient.

$\mathrm{p}=$ Value. in alveolar tissue sections, coincident with the maintenance of the histoarchitecture of the alveolar septa. In contrast, the distal lung parenchyma of OVA-exposed and vehicle-treated animals showed an increase in iNOS positive cells and in the amount of arginase, NF-kB and PGF2 $\alpha$. The $1400 \mathrm{~W}$ and NOR-NOHA treatments in ovalbumin-exposed animals (OVA-NOR-W group) reduced all these parameters below the amounts detected in the OVA group. The association of both treatments caused larger reductions than either treatment alone in isoprostane PGF2 $\alpha$ expression (Figure 8).

\section{Discussion}

Previously, we have already shown that the mainly cells present in airway walls of this asthma model are eosinophils, CD4+ lymphocytes, iNOS and nNOS positive cells $[4,6,24,28]$. In addition, we had demonstrated in distal lung of this animal asthma model that eosinophil density, iNOS positive cells and isoprostane PGF2 $\alpha$ were increased due to the effect of the sensitization process. These histopathologycal alterations were correlated with distal lung mechanics responses either after acethylcholine or antigen challenge $[2,3,28]$.

In the present study, we demonstrated that chronic distal lung inflammation was associated with an increase in arginase content and iNOS positive cells. These results were associated with constriction of the distal lung parenchyma. Drazen, Schneider [33] showed that ultrathin guinea-pig lung strips, which contained no conducting airways or blood vessels, contracted after histamine or carbachol challenge. These investigators concluded that alveolar interstitial cells and/or alveolar duct smooth muscle were responsible for the response. Although in the present study the strips were represented by more than $90 \%$ alveolar walls (Table 2) it was not possible to exclude a constrictor effect of some distal airways and vessels.

The increased iNOS expression leads to activation of the oxidative stress pathway and formation of PGF $2 \alpha$, which had a procontractile effect. In addition, we showed that the mechanism involved in the activation of arginase and the iNOS pathways may be related to the modulation of NF-kB expression. Finally, we demonstrated that the association of both inhibitors potentiated the reduction of isoprostane PGF2 $\alpha$ expression in this animal model.

The efficacy of these treatment protocols was demonstrated by the significant reduction of the number of iNOS-positive cells and arginase content in the lung tissue of animals exposed to ovalbumin and treated with $1400 \mathrm{~W}$ and nor-NOHA, respectively. We confirm previous studies showing that $1400 \mathrm{~W}$ has in vivo selectivity for iNOS [24] and that nor-NOHA is a potent and highly selective inhibitor of arginase [34]. In fact, the nor-NOHA inhibition used is specific for arginase 2. Then the mechanism involved in the modulation of 


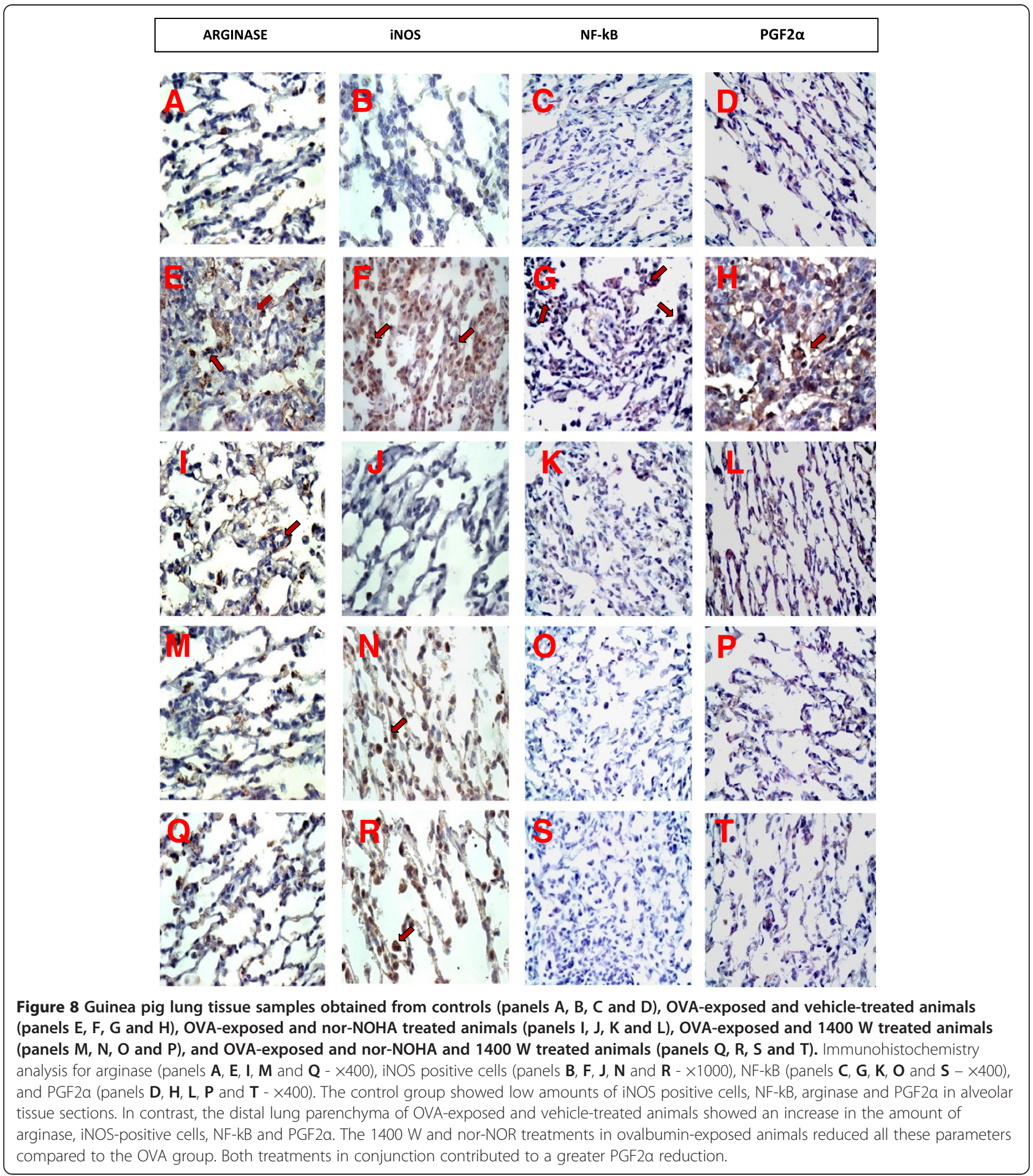

iNOS pathway by arginase is not related to nor-NOHA competition.

Considering the mechanisms involved in an allergic inflammatory microenvironment pro-inflammatory cytokines, like IL-4, IL-1 $\beta$, and tumour necrosis factor $\alpha$ (TNF- $\alpha$ ) and oxidative stress might upregulate the production of iNOS-derived NO through activation of transcription factors, such as signal transcription 1 (STAT1), STAT6 and nuclear factor kB (NF-kB) [35]. In our study, arginase 2 blockade leads to decreased NF-KB expression. The treatment with nor-NOHA also leads to a reduction of iNOS expression. This effect could be explained by the fact that iNOS expression is NF-KB dependent. 
Table 2 Morphometric determination of distal proportions of alveolar septa, airways, and vessels

\begin{tabular}{llll}
\hline Groups & \% of alveolar septa & \% of vessels & \% of airways \\
\hline SAL & $90.7(90.3-90.9)$ & $9.3(8.7-10.7)$ & $0.8(0.6-2.0)$ \\
\hline OVA & $90.3(89.6-91.4)$ & $8.6(7.6-9.1)$ & $1.1(0.9-1.4)$ \\
\hline OVA-NOR & $91.5(92.5-91.5)$ & $7.1(5.7-7.7)$ & $0.6(0.4-0.8)$ \\
\hline OVA-W & $90.2(90.1-90.4)$ & $10.1(9.4-10.6)$ & $0.7(0.4-1.2)$ \\
\hline OVA-NOR-W & $93.1(90.1-93.8)$ & $5.6(6.4-5.7)$ & $0.4(0.6-0.4)$
\end{tabular}

There were no significant differences between the proportions of alveolar septa, airways, and vessels among the five experimental groups. Median (25-75\%).

However, we observed differences in the intensity of the effects of $1400 \mathrm{~W}$ and nor-NOHA on the number of iNOS positive cells. We considered that it may be dependent on the doses and / or the differences between the protocols of treatments used.

It is noteworthy that, we demonstrated for the first time in an animal model of chronic allergic inflammation, an increase in arginase 2 expression in distal lung parenchyma. A number of studies have reported an increase in arginase activity in the airways of both acute and chronic guinea pig models of allergic asthma [18,20]. Increased arginase 2 activity and/or expression have also been demonstrated in other animal models using different antigens, species and strains [36].

Some studies also hypothesized that endogenous arginase activity could affect both the proximal and distal airways. Using a perfused guinea pig tracheal tube preparation, Meurs et al. [18] demonstrated that the potent

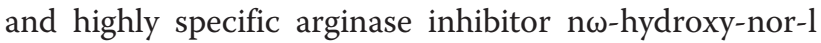
arginine (nor-NOHA) caused a concentration-dependent inhibition of methacholine-induced airway constriction, which was reversed by L-NAME. This result shows that arginase activity in the airways is also involved in the modulation of airway responsiveness by limiting cNOSderived bronchodilating NO production.

Maarsingh et al. [37] showed that in sensitized animals there was an increase in arginase activity, which was completely prevented by the administration of $\mathrm{ABH}$ (an arginase inhibitor). So do we, using a different arginase inhibitor (nor-NOHA). Nonetheless, Maarsingh et al. [37] evaluated the proximal airways while our study was performed in the distal lung parenchyma.

Using a guinea-pig model of allergic asthma, De Boer et al. [38] investigated the role of nitric oxide in allergen induced airway hyperresponsiveness after the early asthmatic reaction by examining the effects of the $\mathrm{NO}$ synthase inhibitor L-NAME on the responsiveness to methacholine and histamine of isolated perfused tracheae from unchallenged and sensitized animals. The authors also demonstrated that a NO deficiency contributes to allergen-induced airway hyperresponsiveness after the early airway responsiveness.

In asthmatic airways, the expression of iNOS is markedly increased by proinflammatory cytokines such as TNF- $\alpha$ and IFN-y in inflammatory cells and in the airway epithelium [39,40]. Prado et al. [7] also found a reduction in iNOS and nNOS positive cells after treatment with this specific iNOS inhibitor $(1400 \mathrm{~W})$ and L-NAME, respectively. Few authors, however, have assessed the effects of inhibition of nitric oxide synthases in modulating the inflammatory and functional responses that occur in the lung parenchyma in the chronic inflammatory response.

In this regard, Angeli et al. [3] analyzed the oscillatory mechanical responses of distal lung tissue in guinea pigs with chronic pulmonary inflammation. The authors observed that sensitized animals treated with L-NAME had a reduction in both lung tissue resistance and elastance after antigen challenge. Starling et al. [2], assessing the distal lung functional changes induced by chronic inflammation, found that treatment with $1400 \mathrm{~W}$ decreased the response of both elastance and resistance in animals exposed to ovalbumin. In conjunction, these studies showed that nitric oxide contributes to the constriction of the pulmonary parenchyma in this experimental model.

Considering that L-arginine is the common substrate for both nitric oxide synthases and for the arginase enzyme, it is possible that blocking one of these enzymatic pathways could affect the other one through competition for the same substrate [20,22]. These enzymes convert L-arginine into L-ornithine and urea and are the key enzymes of the urea cycle in the liver (arginase 1) but are also expressed in cells and tissues that lack a complete urea cycle, e.g., arginase 2 expression in the lung [21]. Arginases are involved in cell growth and tissue repair via the increased production of L-ornithine, a precursor of polyamines and proline [21].

Que et al. [41] demonstrated the expression of arginase in the bronchial epithelium and in peribronchial connective tissue fibroblasts. In addition, Meurs et al. [22] showed that arginase appears to modulate the tone of the airway smooth muscle and potentiates methacholine-induced airway constriction. Arginase accomplishes these actions by forcing the common substrate L-arginine away from epithelial cNOS to diminish the agonist induced production of NO. Arginases and NOS compete for the bioavailability of the same substrate, L-arginine, and are involved indirectly in the regulation of NO synthesis $[18,21]$.

Corroborating this idea, Morris et al. [42] showed that there is a reduction in the levels of plasma arginine in asthmatic patients compared with patients without asthma but with increased serum arginase activity. Together, these results suggest that increased arginase activity in asthma may be a contributing factor to the decrease in the circulating levels of Larginine and the 
consequent NO deficiency. Thus, blocking NO production could be a tool to study the indirect involvement of arginase in various pathophysiological processes [22,43].

Several powerful drugs have been used to investigate the role of arginases in the pathophysiology of asthma, including nor-NOHA ( $\mathrm{N} \omega$-hydroxy-nor-L-arginine), which is one of the most potent inhibitors of arginase [21]. Meurs et al. [22], studying in vitro tracheal ring-sensitized guinea pigs, demonstrated that treatment with nor-NOHA reduced the hyperresponsiveness to methacholine, and this effect was reversed by treatment with L-NAME.

In the present study, we evaluated the effects of arginase 2 inhibition on functional alterations of distal lung parenchyma. We demonstrated that nor-NOHA decreased both the maximal increase in tissue resistance and elastance after ovalbumin challenge in sensitized animals, suggesting that arginase 2 contributes to the modulation of lung parenchyma specific hyperresponsiveness in this experimental model.

One possible explanation for these results may be related to a decrease in the production of bronchodilating $\mathrm{NO}$, presumably through competition with cNOS for the common substrate, L-arginine, as previously shown in other studies discussed above [18]. In the lungs, the constitutive NOS (cNOS) isozymes are mainly expressed in endothelial cells (eNOS), in inhibitory non-adrenergic noncholinergic nerves (nNOS), and epithelial cells (nNOS and eNOS) [38]. However, in the present study we did not evaluate the expression of constitutive nitric oxide enzymes to confirm this possibility.

Interestingly, the animals that were also treated with nor-NOHA showed a lower amount of iNOS positive cells in lung tissue. Our hypothesis is that during the period of the experiment in which the distal lung slices were in contact with nor-NOHA, there was a decrease in NF-kB expression with a subsequent decrease in both arginase 2 and iNOS expression.

To test this hypothesis we evaluated the expression of NF- $k B$ in distal lung tissue from the five experimental groups. We demonstrated that both treatments with $1400 \mathrm{~W}$ and NOR-NOHA diminished the NF-kB expression in sensitized animals. However, the association of $1400 \mathrm{~W}$ and nor-NOHA did not modify this response in sensitized animals. In this sense, Ckless et al. [14] also showed that inhibition or knockdown of arginase caused a small but consistent attenuation of basal and TNF- $\alpha$ stimulated NF-kB transcriptional activity. We also used a specific iNOS inhibitor $(1400 \mathrm{~W})$. In addition, we previously had shown that L-NAME effects were mostly due to constitutive NOS blockade and different forms specific of iNOS inhibitions [6].

$\mathrm{NF}-\mathrm{kB}$ is an essential transcription factor not only for the induction of iNOS, but also for the up-regulation of CAT-2B. The simultaneous up-regulation of CAT-2B with iNOS is considered as a mechanism to ensure a high substrate supply for iNOS. Hammermann et al. (2000) [44] clearly showed that these results were evaluated after 20 hs of culture contact with L-arginine. In addition, we clarified that in the present study. The animals received $1400 \mathrm{~W}$ (iNOS inhibitor) daily during $72 \mathrm{hs}$ before the experiment. Then, this time was sufficient to inhibit NF-KB expression.

We also showed that there was a reduction of 8isoprostane expression in animals exposed to ovalbumin that received either nor-NOHA or $1400 \mathrm{~W}$ treatment. Ogino et al. [45] showed that arginase 1 protein expression in blood serum has recently been associated with PGF2 $\alpha$ in healthy Japanese people and may become a new biomarker for the early prediction of oxidative stressrelated diseases. These findings also corroborate the idea that not only iNOS but also arginase activation increases activation of the oxidative stress pathway. As previously shown, this may have detrimental effects on lung tissue structure [2,3].

Another point to be analyzed is that the association of both inhibitors caused larger reductions than either treatment alone in isoprostane PGF2 $\alpha$ expression. This was sufficient to reduce PGF $2 \alpha$ but did not affect the distal lung mechanical responses. Considering the importance of isoprostanes as contractile agents, we expected that there was a more prominent effect on lung mechanics in animals that received the two inhibitors. In addition, De Boer et al. [46] showed that the increased formation of the highly reactive procontractile and proinflammatory oxidant peroxynitrite plays an important role in airway hyperresponsiveness after the late airway responsiveness. It is possible that differences in the protocols of treatment with these inhibitors and/or different doses may contribute to attenuate the mechanical responses observed. However, this needs to be tested in another study.

Reinforcing the previous results, we showed that the resistance of the distal lung was correlated with the number of iNOS positive cells, isoprostane PGF $2 \alpha$ and NF-kB expression $[28,47]$. In the present study we also showed that arginase 2 was correlated to resistance of distal lung tissue. Another point is that the NF-kB expression was correlated to arginase 2 expression and the number of iNOS positive cells. These results suggested a mechanistic pathway that needs to be further investigated.

Although we had previously mentioned some limitations of the present study, we also note that the results obtained in animal models may not be always applicable in humans. Nevertheless, it is important to remember that the guinea pig model is one of the best animal models to study asthma, as its lung anatomy is similar to humans, and it mimics some of the characteristics of human asthma such as the eosinophilic inflammatory and remodeling process $[4,48]$. Another point is that we 
evaluated the distal lung parenchyma. In fact, more studies need to be performed using chronic treatment with arginase inhibitors in intact animals. In the present study, the main limitation for performing this systemic treatment is the high cost of the drug. Finally, we also need to evaluate not only the expression of iNOS but also the activity of this enzyme, as well as the evaluation of constitutive nitric oxide sintase isoforms.

\section{Conclusions}

In conclusion, this present study demonstrated that increased arginase 2 expression and activity contributes to increased iNOS expression and for the constriction of the distal lung parenchyma, likely due to altered NF-kB expression. These alterations associated with high PGF2 $\alpha$ expression. Treatment with iNOS and arginase specific inhibitors reduced 8-isoprostane expression. The modulation of these pro-inflammatory pathways may represent future pharmacological tools for controlling pulmonary functional alterations induced by chronic inflammation.

\section{Abbreviations}

AW: Alveolar wall; BWW: Blood vessel wall; BW: Bronchial wall; cNOS: Nitric oxide synthase constitutive; eNOS: Endothelial nitric oxide; Et: Tissue elastance; iNOS: Inducible nitric oxide synthase; L-NAME: NG-nitro-L-arginine methyl ester; NF-Kb: Nuclear factor-Kb; nor-NOHA: Nw-hydroxy-nor-Larginine; NO: Nitric oxide; NOS: Nitric oxide synthases; RNS: Reactive nitrogen species; ROS: Reactive oxygen species; Rt: Tissue resistance; 1400W: N-

(3(Aminomethyl) Benzyl) Acetamidine; FAPESP: Foundation for Research Support of the State of São Paulo; LIM-20: Laboratory of Medical Investigation; HC: Hospital and Clinics; FMUSP: Faculty of Medicine, University of São Paulo.

\section{Competing interests}

The authors declare that they have no competing interests.

\section{Authors' contributions}

LRCRBA acquired the data, analyzed and interpreted the data, contributed to design of the study, and drafted and revised the manuscript. RFR, NM, RBF, CMS, JCPS, PA and contributed to acquiring the data, interpretation of data, and drafted parts of the manuscript and made revisions to the manuscript. $E A L, L C C, C M P, M D, M A M$ and IFLCT made the design of the study, contributed to the interpretation of data, and drafted parts of the manuscript and made critical revisions to the manuscript. All authors read and approved the final manuscript.

\section{Acknowledgements}

FAPESP and LIM-20-HC-FMUSP.

\section{Author details}

'Department of Clinical Medicine, School of Medicine, University of Sao Paulo, 01246-903 São Paulo, SP, Brazil. '2Department of Clinical Medicine and Pathology, School of Medicine, University of Sao Paulo, 01246-903 São Paulo, SP, Brazil. ${ }^{3}$ Department of Biological Sciences, Universidade Federal de São Paulo, Diadema, SP, Brazil. ${ }^{4}$ Faculty of Medicine, University of São Paulo, Av. Dr. Arnaldo, 455 - Sala 1210, 01246-903 São Paulo, SP, Brazil.

Received: 10 November 2012 Accepted: 7 August 2013 Published: 15 August 2013

\section{References}

1. Kraft M, Djukanovic R, Wilson S, Holgate ST, Martin RJ: Alveolar tissue inflammation in asthma. Am J Respir Crit Care Med 1996, 154:1505.

2. Starling CM, Prado CM, Leick-Maldonado EA, Lanças T, Reis FG, Aristóteles LR, Dolhnikoff M, Martins MA, Tibério IF: Inducible nitric oxide synthase inhibition attenuates lung tissue responsiveness and remodeling in a model of chronic pulmonary inflammation in guinea pigs. Respir Physiol Neurobiol 2009, 165:185-194.

3. Angeli P, Prado CM, Xisto DG, Silva PL, Passaro CP, Nakazato HD, LeickMaldonado EA, Martins MA, Rocco PR, Tiberio IF: Effects of chronic L-NAME treatment lung tissue mechanics, eosinophilic and extracellular matrix responses induced by chronic pulmonary inflammation. Am J Physiol Lung Cell Mol Physiol 2008, 294:L1197-05.

4. Tibério IF, Turco GMG, Leick-Maldonado EA, Sakae RS, Paiva SO, do Patrocínio M, Warth TN, Silva JR L e, Saldiva PH, Martins MA: Effects of neurokinin depletion on airway inflammation induced by chronic antigen exposure. Am J Respir Crit Care Med 1997, 155:1739-1747.

5. Prado CM, Leick EA, Lopes FDTQS, Martins MA, Tibério IFLC: Different Modulators of Airways and Distal Lung Parenchyma Contractile Responses in the Physiopathology of Asthma, Current Basic and Pathological Approaches to the Function of Muscle Cells and Tissues. In Edited by From Molecules to Humans, Haruo Sugi. ; 2012. ISBN 978-953-51-0679-1.

6. Prado CM, Leick-Maldonado EA, Kasahara DI, Capelozzi VL, Martins MA, Tiberio IF: Effects of acute and chronic nitric oxide inhibition in an experimental model of chronic pulmonary allergic inflammation in guinea pigs. Am J Physiol Lung Cell Mol Biol 2005, 289:L677-L683.

7. Prado CM, Leick- Maldonado EA, Leme AS YL, Capelozzi VL, Martins MA Tibério IF: Effects of nitric oxide synthases in chronic allergic airway inflammation and remodeling. Am J Physiol Lung Cell Mol Biol 2006, 35(4):457-465.

8. Lanças T, Kasahara DI, Prado CM, Tibério FLCl, Martins MA, Dolhnikoff M: Comparison of early and late responses to antigen of sensitized guinea pig parenchymal lung strips. J App/ Physiol 2006, 100(5):1610-1616.

9. Dolhnikoff M, Mauad T, Ludwig MS: Extracellular matrix and oscillatory mechanics of rat lung parenchyma in bleomycin- induced fibrosis. Am J Respir Crit Care Med 1999, 160:1750-1757.

10. Xia Y, Roman $L$, Masters BS, Zweier $J$ : Inducible nitricoxide synthase generates superoxide from the reductase domain. J Biol Chem 1998, 273:22635-22639.

11. Moncada S, Higgs A: The L-arginine-nitric oxide pathway. N Engl J Med 2003, 329(27):2002-2012.

12. Janssen LJ: Isoprostanes: an overview and putative roles in pulmonary pathophysiology. Am J Physiol Lung Cell Mol Physiol 2001, 280(6):L1067-L1082.

13. Prado CM, Martins MA, Tiberio IF: Nitric oxide in asthma physiopathology. ISRN Allergy 2011, 2011:13.

14. Ckless $K$, Van der Vliet $A$, Janssen-Heininger $Y$ : Oxidative nitrosative stress and post-translational protein modifications: implications to lung structurefunction relations. Arginase modulates NF-kappaB activity via a nitric oxide-dependent mechanism. Am J Respir Cell Mol Biol 2007, 36:645-653.

15. Pantano C, Ather JL, Alcorn JF, Poynter ME, Brown AL, Guala AS, Beuschel SL, Allen GB, Whittaker LA, Bevelander M, Irvin CG, Janssen-Heininger YMW: Nuclear factor-B activation in airway epithelium induces inflammation and hyperresponsiveness. Am J Respir Crit Care Med 2008, 177:959-969.

16. Hart L, Lim S, Adcock I, Barnes PJ, Chung KF: Effects of inhaled corticosteroid therapy on expression and DNA-binding activity of nuclear factor kB in asthma. Am J Respir Crit Care Med 2000, 161:224-231.

17. Poynter ME, Cloots R, Van Woerkom T, Butnor KJ, Vacek P, Taatjes DJ, Irvin CG, Janssen-Heininger YM: NF-kB: Activation in airways modulates allergic inflammation but not hyperresponsiveness. J Immunol 2004, 173:7003-7009.

18. Meurs H, Hamer MAM, Pethe S, Goff SV, Boucher J, Zaagsma J: Modulation of cholinergic airway reactivity and nitric oxide production by endogenous arginase activity. Br J Pharmacol 2000, 130:1793-1798.

19. Que LG, Kantrow SP, Jenkinson CP, Piantadosi CA, Huang YC: Induction of arginase isoforms in the lung during hyperoxia. Am J Physiol 1998 275:L96-L102.

20. Maarsingh $\mathrm{H}$, Zaagsma J, Meurs $\mathrm{H}$ : Arginase: a key enzyme in the pathophysiology of allergic asthma opening novel therapeutic perspectives. Br J Pharmacol 2009, 158:652-664.

21. Meurs $H$, Maarsingh $H$, Zaagsma J: Arginase and asthma: novel insights into nitric oxide homeostasis and airway hyperresponsiveness. Trends Pharmacol Sci 2003, 24:450-455.

22. Meurs H, McKay S, Maarsingh H, Hamer M, Macic L, Molendijk N, Zaagsma J: Increased arginase activity underlies allergen-induced deficiency of cNOS derived nitric oxide and airway hyperresponsiveness. $\mathrm{Br} J$ Pharmacol 2002, 136:391-398.

23. Leick-Maldonado EA, Kay FU, Leonhardt MC, Kasahara DI, Prado CM, Fernandes FT, Martins MA, Tibério IFLC: Comparison of glucocorticoid and 
cysteinyl leukotriene receptor antagonist treatments in an experimental model of chronic airway inflammation in guiena-pigs. Clin Exp Allergy 2004, 34:145-152.

24. Prado CM, Leick-Maldonado EA, Miyamoto L, Yano LM, Kasahara DI, Martins MA, Tibério IF: Capsaicin-sensitive nerves and neurokinins modulate non neuronal nNOS expression in lung. Respir Physiol Neurobiol 2008, 160(1):37-44.

25. Garvey EP, Oplinger JA, Furfine ES, Kiff RJ, Laszlo F, Whittle BJR, Knowel RG: $1400 \mathrm{~W}$ is a slow, tight binding and highly selective inhibitor of inducible nitric oxide synthase in vitro and in vivo. J Biol Chem 1997, 272(8):4959-4963.

26. Nagase T, Fukuchi Y, Dallaire MJ, Martin JG, Ludwig MS: In vitro airway and tissue responses to antigen in sensitized rats. Am J Respir Crit Care Med 1995, 153:81-86.

27. Lauzon AM, Bates HT: Estimation of time-varying respiratory mechanical parameters by recursive least squares. J App/ Physiol 1991, 71:1159-1165.

28. Nakashima AS, Prado CM, Lanças T, Ruiz VC, Kasahara DI, Leick-Maldonado EA, Dolhnikoff M, Martins MA, Tibério IF: Oral tolerance attenuates changes in invitro lung tissue mechanics and extracellular matrix remodeling induced bychronic allergic inflammation in guinea pigs. J Appl Physiol 2008, 104(6):1778-1785.

29. Weibel ER: The challenge of measuring lung structure. On the "Standards for the Quantitative Assessment of Lung Structure". Nihon Kokyuki Gakkai Zasshi 2010, 48(9):637-643.

30. Coers W, Timens W, Kempinga C, Klok PA, Moshage H: Specificity of antibodies to nitric oxide synthase isoforms in human, guinea pig, rat and mouse tissues. J Histochem Cytochem 1998, 46:1385-1392.

31. Montuschi P, Corradi M, Ciabattoni G, Nightingale J, Kharitonov SA, Barnes PJ: Increased 8-isoprostane, a marked of oxidative stress, in exhaled condensation in asthma patients. Am J Respir Crit Care Med 1999, 160:216-220.

32. Zar JH: Biostatistical Analysis. 2nd edition. Englewood Cliffs, New Jersey, USA: Prentice-Hall Inc; 1984:206-235.

33. Drazen JM, Schneider MW: Comparative responses of tracheal spirals and parenchymal strips to histamine and carbachol in vitro. J Clin Invest 1978, 61:1441-1447

34. Custot J, Moali C, Brollo M, Boucher JL, Delaforge M, Mansuy D, Tenu JP, Zimmermann JL: The new alpha-amino acid N-omega-hydroxy-nor-Larginine: a high affinity inhibitor of arginase well adapted to bind to its manganese cluster. J Am Chem Soc 1996, 119:4086-4087.

35. Ricciardolo FL: cNOS - Inos paradigm and arginase in asthma. Trends Pharmacol Sci 2003, 24:560-561.

36. Maarsingh $H$, Zuidhof AB, Bos IS, Van Duin M, Boucher JL, Zaagsma J, Meurs $\mathrm{H}$ : Arginase inhibition protects against allergen-induced airway obstruction, hyperresponsiveness, and inflammation. Am J Respir Crit Care Med 2008, 178:565-573.

37. Maarsingh H, Dekkers BGJ, Zuidhof AB, Bos IST, Menzen MH, Klein T, Flik G, Zaagsma J, Meurs $\mathrm{H}$ : Increased arginase activity contributes to airway remodelling in chronic allergic asthma. Eur Respir J 2011, 38:318-328.

38. De Boer J, Meurs H, Coers W, Koopal M, Bottone AE, Visser AC, Timens W, Zaagsma J: Deficiency of nitric oxide in allergen-induced airway hyperreactivity to contractile agonists after the early asthmatic reaction: an ex vivo study. Br J Pharmacol 1996, 119:1109-1116.

39. Barnes PJ, Chung KF, Page CP: Inflammatory mediators of asthma: an update. Pharmacol Rev 1998, 50:515-596.

40. Asano K, Chee CB, Gaston B, Lilly CM, Gerard C, Drazen JM, Stamler JS: Constitutive and inducible nitric oxide synthase gene expression, regulation, and activity in human lung epithelial cells. Proc Natl Acad SCi 1994, 9:10089-10093.

41. Que LG, George SE, Gotoh T, Mori M, Huang YC: Effects of arginase isoforms on NO production by nNOS. Nitric Oxide 2002, 6:1-8.

42. Morris CR, Poljakovic M, Lavrisha L, Machado L, Kuypers FA, Morris SM: Decreased arginine bioavailability and increased serum arginase activity in asthma. Am J Respir Crit Care Med 2004, 170:148-53.

43. Ricciardollo FL, Sterk PJ, Gaston B, Folkers G: Nitric oxide in health and disease of the respiratory system. Physiol Rev 2004, 84:731-765.

44. Hammermann R, Dreißig MDM, Mössner J, Fuhrmann M, Berrino L, Göthert $M$, Racké K: Nuclear factor-KB mediates simultaneous induction of inducible nitric-oxide synthase and Up-regulation of the cationic amino acid transporter CAT-2B in Rat alveolar macrophages. Mol Pharmacol 2000, 58:1294-1302

45. Ogino K, Takahashi N, Takigawa T, Obase Y, Wang D: Association of serum arginase I with oxidative stress in a healthy population. Free Research 2011, 45:147-155.
46. De Boer J, Meurs H, Flendrig L, Koopal M, Zaagsma J: Role of nitric oxide and superoxide in allergen-induced airway hyperreactivity after the late asthmatic reaction in guinea-pigs. Br J Pharmacol 2001, 133:1235-1242.

47. Possa SS, Charafeddine HT, Righetti RF, Silva PA, Almeida-Reis R, SaraivaRomanholo BM, Perini A, Prado CM, Leick-Maldonado EA, Martins MA, Tibério ID: Rho-kinase inhibition attenuates airway responsiveness, inflammation, matrix remodeling and oxidative stress activation induced by chronic inflammation. Am J Physiol Lung Cell Mol Physiol 2013, 46:1-9.

48. Ricciardolo FL, Frans N, Rose VD, Gert F: The Guinea Pig as an animal model for asthma. Curr Drug Targets 2008, 9:452-465.

doi:10.1186/1471-2466-13-52

Cite this article as: Aristoteles et al:: Modulation of the oscillatory mechanics of lung tissue and the oxidative stress response induced by arginase inhibition in a chronic allergic inflammation model. $B M C$ Pulmonary Medicine 2013 13:52.

\section{Submit your next manuscript to BioMed Central and take full advantage of:}

- Convenient online submission

- Thorough peer review

- No space constraints or color figure charges

- Immediate publication on acceptance

- Inclusion in PubMed, CAS, Scopus and Google Scholar

- Research which is freely available for redistribution

Submit your manuscript at www.biomedcentral.com/submit
C) Biomed Central 